\title{
The naturalized species of Lupinus (Fabaceae) in southern Africa
}

\section{H. STIRTON*}

Keywords: Fabaceae, Lupinus, naturalization, southem Africa

\section{ABSTRACT}

Four species of Lupinus have become naturalized in southern Africa: $L$. consentinii Guss., $L$. angustifolius L., $L$. pilosus Murray and $L$. luteus L. Their morphological variation and geographical distribution is discussed and a key is provided.

\section{UITTREKSEL}

Vier Lupinus-spesies het in suidelike Afrika genaturaliseerd geraak: $L$. consentinii Guss., $L$. angustifolius $L$., $L$. pilosus Murray en $L$. luteus $L$. Hulle morfologiese variasie en geografiese verspreiding word bespreek en 'n sleutel word voorsien.

\section{INTRODUCTION}

The genus Lupinus comprises some 200 species of annual and perennial herbs, or sometimes subshrubs (Polhill 1976; Bisby 1981). It is best represented in the western parts of North and South America, with a second centre in Mediterranean Europe with some extensions into the highlands of eastern Africa (Kay 1979). Twelve species of European and African origin are recorded from Africa (Gladstones 1974; Plitmann 1981; Williams, Demissie \& Harborne 1983).

Lupins have been used by man for thousands of years, principally for fodder, green manure, ornament and as grain legumes. A few species have become naturalized weeds in Mediterranean Europe, the south-east United States of America, the Andes, Australia, New Zealand and South Africa (Kay 1979).

The taxonomy of the genus has been confused for a long time. This was exacerbated to some extent by the development and growing importance of large-seeded lupins as a source of edible protein (Gladstones 1974). The most important grain legumes are Lupinus albus L., L. angustifolius $\mathrm{L}$., L. luteus $\mathrm{L}$. and $L$. mutabilis Sweet.

Recent studies on the flavonoid chemistry of the Old World species of Lupinus provide useful taxonomic markers (Williams et al. 1983) to separate the species cultivated or naturalized in southern Africa. $L$. albus has flavonols only, $L$. angustifolius and $L$. luteus have flavones and flavonols, whereas $L$. consentinii and $L$. pilosus are characterized by the presence of flavone C-glycosides, luteolin and novel 2 'hydroxyflavone. L. angustifolius is chemically distinct from all the other Old World species as it accumulates diosmetin derivatives as major leaf constituents (Williams et al. 1983). It is chemically the most variable species and is divided into a number of varieties (Plitmann 1966).

* B. A. Krukoff Botanist, The Herbarium, Royal Botanic Gardens, Kew, Richmond, Surrey, TW9 3AE, UK. Current address: CSIR Unit for Plant Growth and Development, Department of Botany, University of Natal, P.O. Box 375, Pietermaritzburg 3200.

MS. received: 1986.09.05.
The commercial exploitation of lupins in South Africa began early this century but it was C.C.P. Wagener who first drew attention to the importance of the crop (Van Vuuren 1962). He used bitter lupins as fodder for sheep. Prior to that the crop had been used as a green-manuring crop in vineyards and orchards. By 1947 lupins had become part of crop rotations in the wheatbelt of the Cape (Preller 1949; Henning 1949). The introduction of sweet lupins at about that time did much to increase wheat yields and resulted in a substantial increase in the number of livestock animals that could be maintained in the region.

Fourteen cultivars were available in 1962 (Van Vuuren 1962): 1, L. albus: albus (German origin), carstens, pflugs gela, pflugs ultra, and S.S.K. (white sweet); $2, L$. angustifolius: borre, jackalsfontein, ligvoet, S. E. blue No. 1, B. resistant, blue sweet (German origin) and 7002 (white); 3, L. luteus: S. E. yellow No. 1 and weiko III. The weiko III cultivar is an alkaloid-free, white-seeded and early maturing strain and is the dominant lupin cultivated in a number of European countries. A similar strain named Stellenbosch-Elsenburg Geel-1 is popular in South Africa. Lupins are still popular in the western Cape and have begun to be used in other parts of South Africa, for example, in the south-eastern Transvaal Highveld (Van Zyl 1973).

It was perhaps inevitable that as lupins became increasingly popular some species would become naturalized. This study, based on herbarium material as well as fresh specimens collected during three field trips to the region in 1975, 1976 and 1984, is a first attempt to monitor the spread of naturalized lupins in the Cape. It should be stressed, however, that the distribution maps (Figures 1-4) are only an indication of the extent of naturalization. Botanists, farmers and extension-officers are urged to collect herbarium material from areas which are not recorded in this survey. The author will provide identifications of any well pressed, vouchered material that is sent to him.

The descriptions and keys are based on fresh material and cover naturalized species only. 


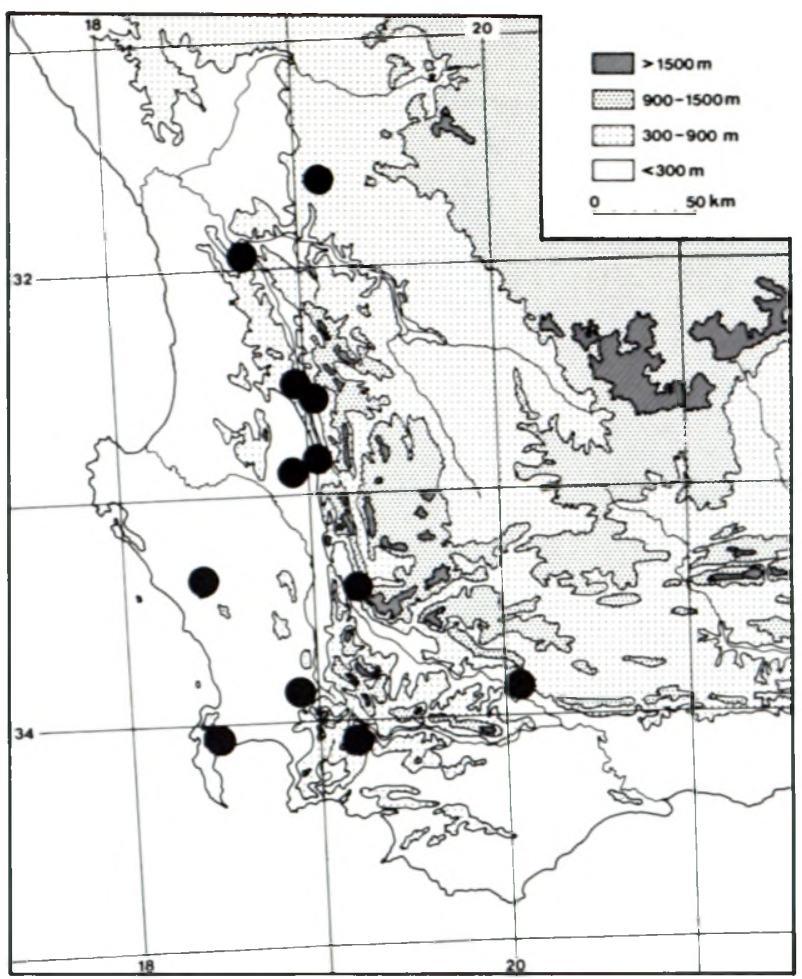

FIGURE 1.-Naturalized distribution of $L$. angustifolius in South Africa.

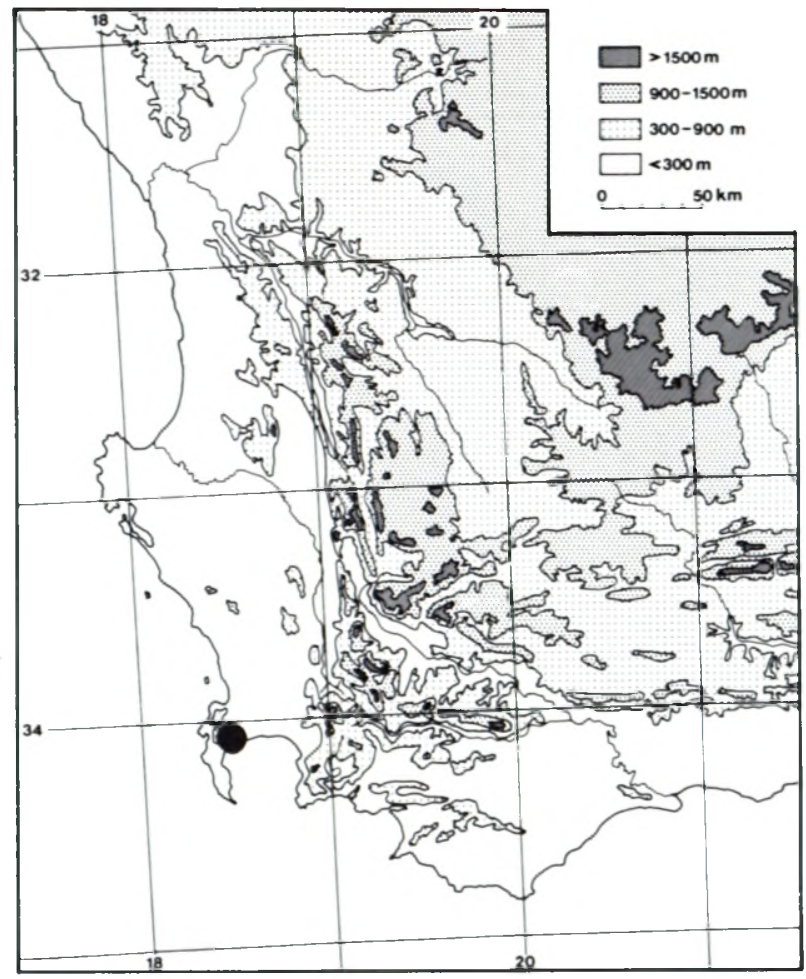

FIGURE 3.-Naturalized distribution of L. pilosus in South Africa.

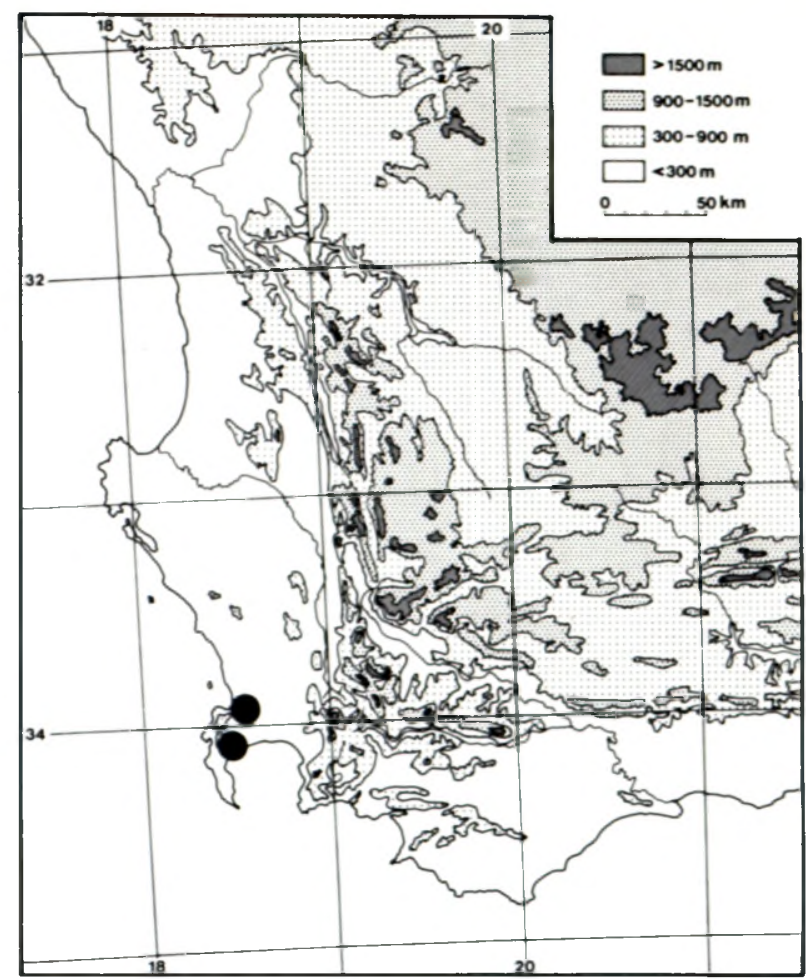

FIGURE 2.-Naturalized distribution of $L$. consentinii in South Africa.

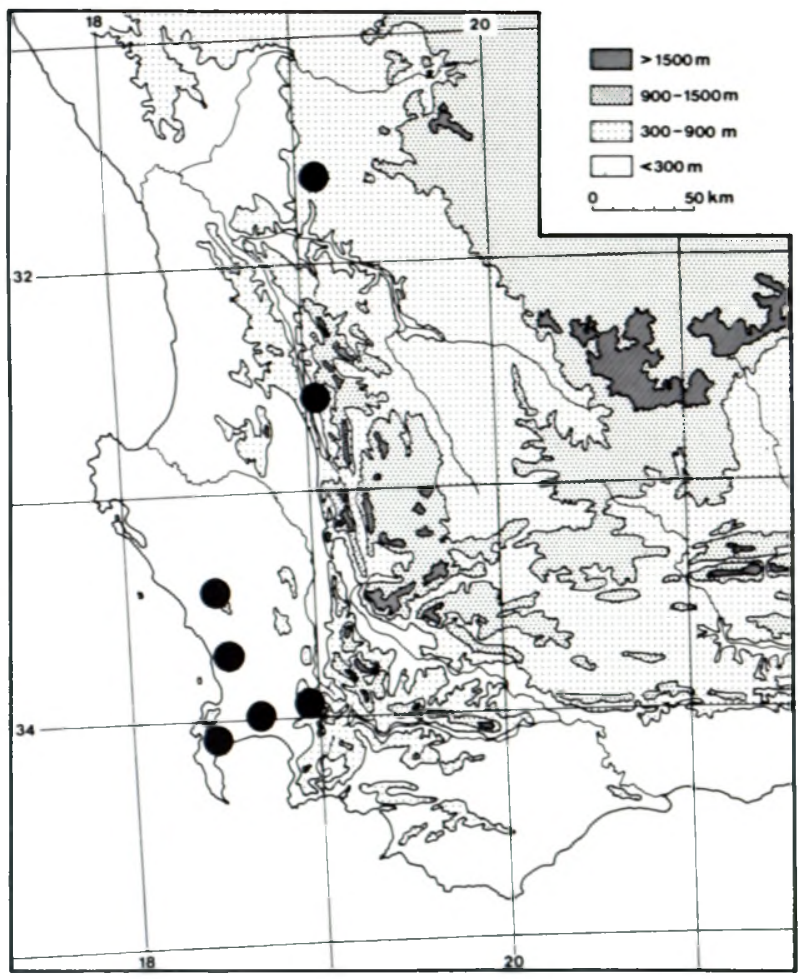

FIGURE 4.-Naturalized distribution of $L$. luteus in South Africa.

2a Leaflets $8-11,40-80 \times 11-21 \mathrm{~mm}$, flattened out, oblanceolate, upper surface finely sericeous; stipules 10-11 mm long; flowers $18-19 \mathrm{~mm}$ long, keel obtuse to acute; bracteoles extending past the sculpturing pattern on the wing petals ............................................................................. 1. consentinii

$2 b$ Leaflets 7-9. 25-27 $\times 4.5-5.0 \mathrm{~mm}$. folded, linear-spathulate, upper surface glabrous: stipules 7-8 mm long; flowers $15 \mathrm{~mm}$ long, keel rostrate: bracteoles shorter than the sculpturing pattern on the wing petals 
1b Flowers pink or yellow:

3a Flowers pink; plants densely hirsute, hairs up to 4,5 mm long; leaflets $14-20 \mathrm{~mm}$ wide. obovate; bracteoles

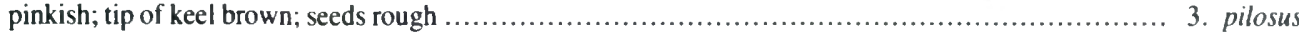

3b Flowers yellow; plants sparsely hirsute; leaflets 5-12 mm wide, narrowly obovate; bracteoles black; tip of

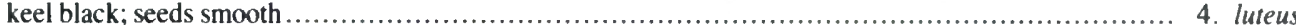

\section{KEY TO DISTINCTIVE FEATURES}

A. Apex of petiole, where the leaflets emerge, distinctly domed .............................................. consentini Apex of petiole, where the leaflets emerge, flattened angustifolius, luteus, pilosus

B. Stipules recurved angustifolius, luteus Stipules straight consentinii, pilosus

C. Stipules shaggy Stipules pubescent pilosus

. Upper surface of leaflets glabrous ................... angustifolius Upper surface of leaflets pubescent...... consentinii, luteus, pilosus

E. Flowers blue ......................... angustifolius, consentinit Flowers pink Flowers yellow pilosus Flowers white luteus

1. Lupinus consentinii Guss., Florae siculae prodromus 2: 398 (1828). For a detailed synonym listing see Gladstones: 29 (1972) and Gladstones: 21 (1974).

Robust annual up to $1 \mathrm{~m}$ tall, erect with vigorous lateral branching, covered in shortly villous $1 \mathrm{~mm}$ long patent hairs. Stipules 10-11 mm long, linear-subulate. straight, arching back towards branch, pubescent. Leaflets 8-11, 40-80 × 14-21 mm, oblanceolate, midrib prominent, apex blunt with a point, base cuneate, finely sericeous above and below; petiole $85-135 \mathrm{~mm}$ long, terete for most of its length but flattened adaxially towards the base. Inflorescences axillary, verticillate, lowest verticil quintuplicate sometimes subalternate, 25-(40)-flowered, 60-180 mm long. Flowers 18-19 $\mathrm{mm}$ long, on stout $5 \mathrm{~mm}$ long pedicels; bract $6-7 \mathrm{~mm}$ long, lanceolate, early caducous; bracteoles linear. $\mathrm{Ca}$ lyx 10-12 mm long; upper lobes deeply divided; lower lobes much longer, fused but shallowly 3-toothed, villous. Corolla 15-16 × 14-18 mm, dull violet-blue darkening with age, nectar patch white turning lilac after anthesis; scentless. Standard $17-18 \mathrm{~mm}$ long and wide, very broadly ovate, scarcely clawed or auriculate, apex rounded. Wing petals $15 \mathrm{~mm}$ long, barely longer than keel petals, dull violet-blue; fused at apex; claw $2 \mathrm{~mm}$ long; sculpturing on upper basal parts comprising 10 rows of 14-20 intercostal lunae. Keel petals $14 \mathrm{~mm}$ long; fused halfway along the base to the acute apex, tip pigmented. Androecium $15 \mathrm{~mm}$ long; anthers dimorphic, comprising 5 basifixed, linear anthers $1,2 \mathrm{~mm}$ long, and 5 medifixed, reniform anthers $0,5 \mathrm{~mm}$ long. Pistil 13 $\mathrm{mm}$ long; ovary $8 \mathrm{~mm}$ long, densely shaggy, height of curvature $5 \mathrm{~mm}$. Fruits $40-50 \times 13-15 \mathrm{~mm}$, densely villous, apple-green, rostrate, segmented. Seeds 4 , rough. Figure 5B.

Lupinus consentinii is most commonly confused with $L$. angustifolius but it is easily separated from that species by its much longer, wider, open, oblanceolate leaflets and obtuse to acute keel petals. Flowering takes place in August and September.
2. L. angustifolius $L$., Species plantarum: 721 (1753); Gladstones: 28 (1972). Holotype: Linnaean Collection 898.7 (LINN).

Erect annual up to $150 \mathrm{~mm}$ high, compact, with profuse lateral branching; finely appressed puberulent. Stipules 7-8 mm long, linear-subulate, recurved, pubescent, glabrous above. Leaflets $7-9,25-27 \times 4,5-5,0$ $\mathrm{mm}$, conduplicate, linear to linear-spathulate, upper surface glabrous, lower surface sparsely sericeous; petiole $35-45 \mathrm{~mm}$ long, adaxial surface flattened, somewhat canaliculate. Inflorescences axillary, on short shoots, with flowers generally alternate towards base but subverticillate towards apex, 5-30-flowered, 50-170 mm long, subsessile but elongating in fruit. Flowers $12-15$ $\mathrm{mm}$ long, on 2-4 mm long pedicels; bract $7 \mathrm{~mm}$ long, oblanceolate to ovate, caducous; bracteoles $2-3 \mathrm{~mm}$ long, oblong. Calyx 9-10 mm long; upper lobes deeply divided; lower lobes united into a longer lip, entire or irregularly 3-toothed, bluish, appressed pubescent. $\mathrm{Co}$ rolla $12-15 \mathrm{~mm}$ long, $9 \mathrm{~mm}$ wide, lavender to bluish, rarely pure white, upper margin of wing petals turns pink after anthesis. Standard 12-13 $\times 9-10 \mathrm{~mm}$. elliptic, shortly clawed, auricles absent, apex truncate. Wing petals $12 \mathrm{~mm}$ long, $5 \mathrm{~mm}$ wide, longer than keel petals, lavender, fused at apex; claw $2 \mathrm{~mm}$ long; sculpturing on upper basal parts comprising 5 rows, each with $20-25$ intercostal lunae. Keel petals $11 \mathrm{~mm}$ long, $3,5 \mathrm{~mm}$ wide, rostrate, sharply upcurved, tip deep purple. Androecium $12 \mathrm{~mm}$ long; anthers dimorphic, comprising 5 basifixed. elongated, $0,9 \mathrm{~mm}$ long anthers and 5 short, medifixed. $0,3 \mathrm{~mm}$ long anthers; pollen orange. Pistil $12 \mathrm{~mm}$ long; ovary $4 \mathrm{~mm}$ long, densely shaggy, height of curvature 3 $\mathrm{mm}$. Fruit $40-50 \times 7-8 \mathrm{~mm}$, villous, pale applegreen. Seeds 5-7, smooth. Figure 5A.

The differences between this species and the only other blue-flowered species, $L$. consentinii, are given under the former. White-flowered morphs are known to occur in L. angustifolius. It is distinguished from the other three species by the glabrousness of the upper surface of the leaflets.

Flowering occurs between August and October. This is the most weedy of the naturalized lupins in South Africa. It can eventually form large stands where it has become established.

3. L. pilosus Murray in L., Systema vegetabilium, edn 13: 545 (1774). The complicated synonymy and typification of this species is outlined in Gladstones (1974).

Erect, $350-700 \mathrm{~mm}$ tall, sparsely branched annual. Stems, petioles and peduncles all clothed in $4.5 \mathrm{~mm}$ long, soft white hairs. Stipules $10-14 \mathrm{~mm}$ long, linearsubulate, straight, more or less parallel to the subtending branch, shaggy. Leaflets $9,40-60 \times 14-20 \mathrm{~mm}$, obovate. finely appressed villous on both sides, partly conduplicate; petioles $50-60 \mathrm{~mm}$ long, adaxially flattened 


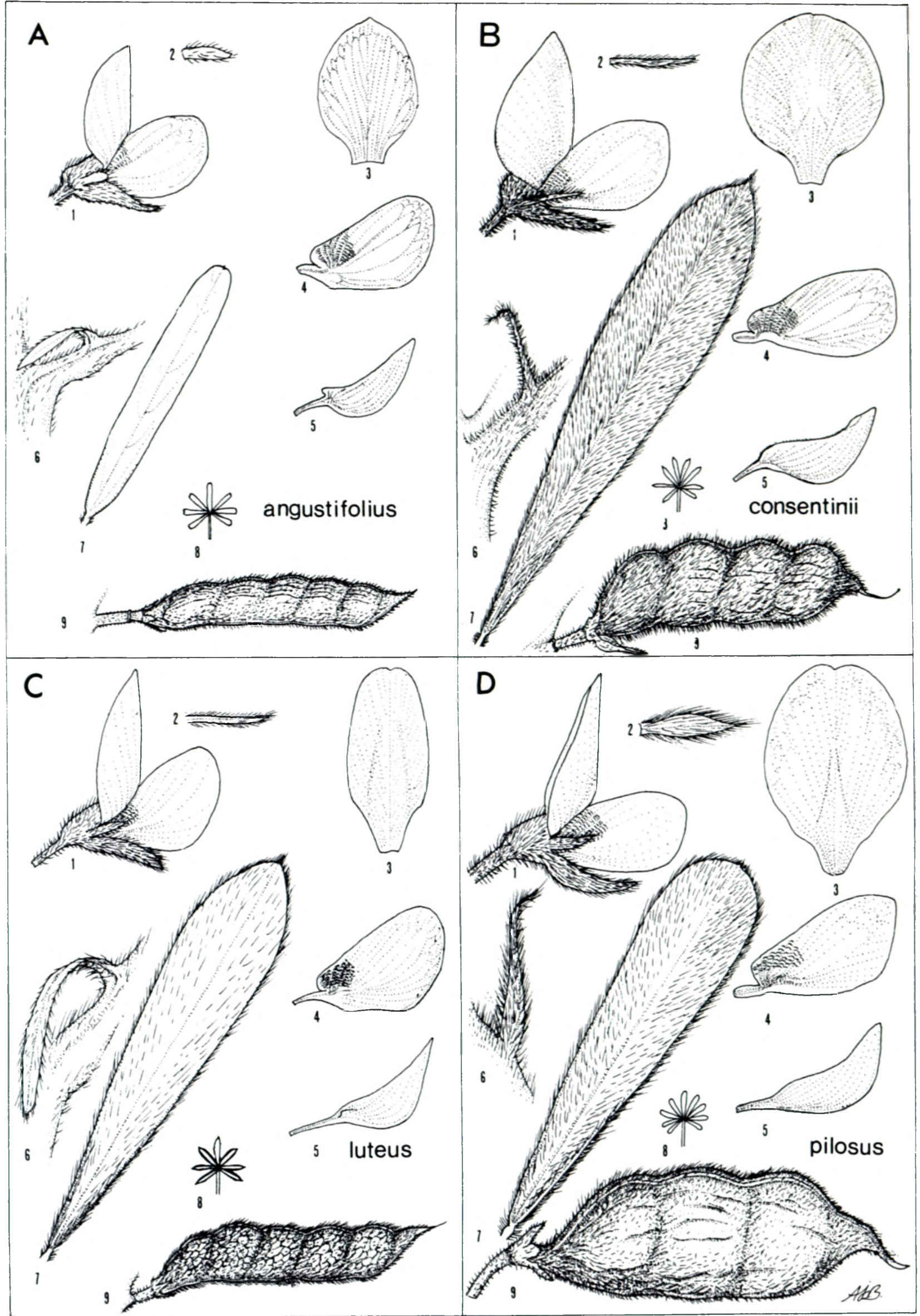

FIGURE 5.-Naturalized species of Lupinus in South Africa: A, L. angustifolius; $B, L$. consensinii; $\mathrm{C}, L$. luteus; $\mathrm{D}, L$. pilosus. 1, flower, $\times$ $2 ; 2$, bracteole, $\times 4 ; 3$, standard, $\times 2 ; 4$, wing petal showing lunate sculpturing, $\times 2 ; 5$, keel petal, $\times 2 ; 6$, junction of the petiole with the stem, showing shape and orientation of the stipule, $\times 2 ; 7$. upper surface of middle leaflet, $\times 2 ; 8$, basic shape of leaf; 9, fruit, $\times 1$. 
towards the base. Inflorescences axillary, lax, 12-16 mm long; peduncle stout; 20-30-flowered, subverticillate proximally, verticillate distally. Flowers large, 20 $\mathrm{mm}$ long, $25 \mathrm{~mm}$ high; pedicels $6-7 \mathrm{~mm}$ long; bract 10-13 $\times 5 \mathrm{~mm}$, boat-shaped, caducous; bracteoles 5 $\mathrm{mm}$ long, lanceolate. Calyx $13 \mathrm{~mm}$ long; upper lobes deeply cleft, widely spaced; lower lobes united, entire, longer than upper ones; tinged with pink. Corolla pink. Standard 22-24 mm long and wide, ovate, pink with large white nectar guide, turning rose after anthesis, grooved on inner face; claw 4-5 mm long, broad. Wing petals $18-19 \times 9-10 \mathrm{~mm}$, pale pink but whiter towards the claw; claw $4 \mathrm{~mm}$ long, twisted. Keel petals $16 \times 5$ $\mathrm{mm}$, rostrate; apex brown-tipped. Androecium $18 \mathrm{~mm}$ long; anthers dimorphic, comprising 5 basifixed, elongated anthers $2 \mathrm{~mm}$ long, alternating with 5 shorter, 1 $\mathrm{mm}$ long, medifixed anthers; pollen orange. Pistil 14 $\mathrm{mm}$ long; ovary $10 \mathrm{~mm}$ long, shaggy; stigma penicillate, forward sloping; height of curvature $6 \mathrm{~mm}$. Fruits 50-80 × 20-25 mm, hirsute, yellow-green. Seeds 3-4. Figure 5D.

Lupinus pilosus is distinguished by its shaggy stipules, densely hairy fruits and pink flowers. Flowering occurs from late July to October.

4. L. luteus $L$., Species plantarum: 721 (1753); Gladstones: 28 (1972) for full synonymy. Holotype: Linnaean Collection 898.8 (LINN).

Herbaceous annual up to $700 \mathrm{~mm}$ tall; rosetted initially but later becoming erect with vigorous basal branching; lightly hirsute. Stipules of stem leaves 12-20 $\times 2-5 \mathrm{~mm}$, smaller on rosette leaves, subulate, recurved, pubescent but glabrous on lower half of inner face. Leaflets 7-9(10), 33-55 × 5-12 mm, narrowly obovate, mucronate, villous above and below, partly conduplicate; petioles $70-90 \mathrm{~mm}$ long, adaxially flattish, shallowly channelled. Inflorescences axillary, 13-17 mm long, elongating in fruit, verticillate, 25-45-flowered; peduncle 5-7 mm long. Flowers 14-15 mm long, yellow; pedicels 2-3 mm long, weak; bract $4 \mathrm{~mm}$ long, obovate, scoop-like, early caducous, black; bracteoles 4-5 mm long, linear, black. Calyx 7-8 mm long; lobes equal, pubescent; upper lobes deeply divided; lower lobes united, shallowly 3-toothed, tips of lobes tinged with black. Corolla chrome-yellow, sweetly scented. Standard $15-17 \times 10-11 \mathrm{~mm}$, narrowly ovate; claw $3 \mathrm{~mm}$ long; apex emarginate, front of standard channelled; auricles weakly developed. Wing petals $15-16 \times 3-4 \mathrm{~mm}$; claw 3-4 mm long; tips fused; sculpturing in upper basal parts with $6-7$ rows of 15-20 intercostal lunae. Keel petals 13-14 × 3-4 $\mathrm{mm}$, rostrate, sharply upcurved, tip black. Androecium $14 \mathrm{~mm}$ long; anthers dimorphic, comprising 5 basifixed, elongated, 1,5 mm long anthers alternating with 5 medifixed, ovate, $0,3 \mathrm{~mm}$ long anthers; pollen yellow. Pistil $12 \mathrm{~mm}$ long; ovary $6 \mathrm{~mm}$ long, densely appressed shaggy; height of curvature $6 \mathrm{~mm}$. Fruits $45-50 \times$ $11-13 \mathrm{~mm}$, reticulate, densely villous, olive-green. Seeds 2-4, smooth. Figure 5C.
Lupinus luteus is distinguished by its bright yellow flowers and distinctly reticulate, densely villous fruits. Flowering occurs in August and September.

\section{ACKNOWLEDGEMENTS}

I would like to thank Miss D. Snijman and Miss P. Perry (Kirstenbosch) for their generous help during this study. The guest house facilities at the National Botanic Gardens, Kirstenbosch have been host to many botanists; their utility to visiting scientists cannot be overestimated. I thank the Curators and staff of BM, BOL, GRA, K, MO, NH, NU, PRE and STE for their help in locating material and its loan where available. Miss Angela Beaumont kindly drew the composite plate, published with permission of R. B. G. Kew. Finally, I wish to acknowledge the support of the Royal Botanic Gardens, Kew, and the Missouri Botanical Garden in sustaining my Research Fellowship.

\section{REFERENCES}

BISBY, F.A. 1981. Genisteae (Adans.) Benth. In R. M. Polhill \& P. H. Raven, Advances in legume systematics: 409-425. Royal Botanic Gardens, Kew.

GLADSTONES, J. S. 1972. Lupins in Western Australia. Department of Agriculture, Western Australia, Bulletin No. 3834.

GLADSTONES, J. S. 1974. Lupins of the Mediterranean region and Africa. Technical Bulletin No. 26, Western Australian Department of Agriculture.

GUSSONE, G. 1828. Florae siculae prodromus 2: 398. Naples.

HENNING, P. O. 1949. Lupines in the winter rainfall area. Farming in South Africa 24: 227-236.

KAY, D.E. 1979. Food legumes. Tropical Products Institute, London.

LINNAEUS, C. 1753. Species plantarum: 721. Stockholm.

LINNAEUS, C. 1774. Systema vegetabilium, edn 13: 545. Göttingen.

PLITMANN, U. 1966. Studies in the taxonomy of the Leguminosae of Israel. Israel Journal of Botany 15: 25-30.

PLITMANN, U. 1981. Evolutionary history of the Old World Lupines. Taxon 30: 430-437.

POLHILL, R. M. 1976. Genisteae (Adans.) Benth. and related tribes (Leguminosae). Botanical Systematics 1: 143-368.

PRELLER. J. H. 1949. Lupines. Farming in South Africa 24: 25-29.

VAN VUUREN, P. J. 1962. How to identify lupins. Farming in South Africa 38.9:61-64.

VAN ZYL, L. G. 1973. Lupins in the south-eastern Transvaal Highveld. Farming in South Africa 48: 4-7, 10.

WILLIAMS, C. A., DEMISSIE, A. \& HARBORNE, J. B. 1983. Flavonoids as taxonomic markers in Old World Lupinus species Biochemical Systematics and Ecology 11: 221-231.

\section{SPECIMENS EXAMINED}

Bos 28 (2) STE. Cloete s.n. (4) STE. Markötter s.n. (2) STE 19310 Snijman 882 (2) K, NBG. PRE: 883 (4) K, NBG, PRE: 884 (2) K NBG. PRE; 886 (2) K. NBG. PRE; $903 a$ (2) K. NBG, PRE: 908 (4) K. NBG, PRE. Stirion 502 l (1) PRE: 5036 (4) K. PRE; 5037 (2) K. PRE: 5882 (2) K. PRE: 5940 (2) K. PRE: 6129 (2) K. PRE: $1075 /$ (1) NBG: 10752 (3) NBG; 10753 (4) NBG; 10762 (2) NBG; 10765 (4) NBG Vahrmeijer 2321 (2) PRE. Cultivated specimens: Codd s.n. (3) K Henning s.n. (1) K. 
